\title{
Pentingnya Peran Pasien dan Keluarga dalam Mencegah Terjadinya Bahaya dan Adverse di Pusat Layanan Kesehatan
}

\author{
Sri Rezeki Silalahi
}

\author{
$\underline{\text { Srisilalahi2604@gmail.com }}$
}

\section{Latar Belakang}

Keselamatan pasien sebagai suatu sistem memberikan asuhan kepada pasien lebih aman, mencegah cedera akibat kesalahan karena melakukan tindakan atau tidak melakukan tindakan yang seharusnya dilakukan. Insiden keselamatan pasien meliputi kesalahan medis (medical errors), kejadian yang tidak diharapkan (adverse event), dan nyaris terjadi (near miss). Undang-undang Nomor 44 Tahun 2009 tentang Rumah Sakit bertujuan memberikan perlindungan kepada pasien, masyarakat, dan sumber daya manusia, mempertahankan dan meningkatkan mutu pelayanan rumah sakit, serta memberi kepastian hukum kepada masyarakat dan rumah sakit. Untuk menjamin keselamatan pasien, maka organisasi pelayanan kesehatan harus mampu membangun sistem yang membuat proses keperawatan pasien lebih amna, baik bagi pasien, petugas kesehatan, maupun masyarakat sekitarnya (keluarga, pengunjung), serta management rumah sakit. Sistem keselamatan pasien ditujukan untuk mengurangi resiko, mencegah terjadinya cedera akibat proses pelayanan pasien, serta tidak terulangnya insiden keselamatan pasien melalui penciptaan sistem keselamatan pasien. Bagi managemen, penciptaan sistem keselamatan pasien merupakan bentuk akuntabilitas rumah sakit terhadap pasien dan keluarga. Keselamatan menjadi isu global dan terangkum dalam lima isu penting yang terkait di rumah sakit yaitu keselamatan pasien, keselamatan pekerja atau petugas kesehatan, keselamatan bangunan dan peralatan di rumah sakit, keselamatan lingkungan dan keselamatan bisnis rumah sakit yang terkait dengan kelangsungan hidup rumah sakit. Mengingat masalah keselamatan pasien merupakan masalah yang perlu ditangani segera maka diperlukan standar keselamatan pasien fasilitas pelayanan kesehatan yang merupakan acuan untuk melaksanakan kegiatannya. Perilaku yang tidak aman, lupa, kurangnya perhatian/motivasi, kecerobohan, tidak teliti dan kemampuan yang tidak memperdulikan dan menjaga keselamatan pasien berisiko untuk terjadinya kesalahan dan akan mengakibatkan cedera pada pasien. 


\section{METODE}

Jurnal ini menggunakan metode literature review dari berbagai sumber seperti buku referensi jurnal dan juga membandingkan beberapa jurnal yang berhubungan dengan pentingnya peran pasien dan keluarga dalam mencegah terjadinya bahaya dan adverse di pusat layanan kesehatan. Dari analisis berbagai sumber yang digunakan untuk mengetahui pentingnya peran pasien dan keluarga dalam mencegah terjadinya bahaya dan adverse di pusat layanan kesehatan. Pengolahan jurnal dilakukan dengan metode membandingkan beberapa jurnal yang berkaitan dengan pentingnya peran pasien dan keluarga dalam mencegah terjadinya bahaya dan adverse di pusat layanan kesehatan.

\section{HASIL}

Keselamatan dan keamanan merupakan kebutuhan dasar manusia. Keselamatan juga merupakan hal yang paling penting dalam setiap pelayanan kesehatan, sehingga dapat dikatakan bahwa keselamatan merupakan tanggung jawan dari pemberi jasa pelayanan kesehatan. Pelayanan kesehatan terutama pelayanan keperawatan di setiapunit perawatan baik akut maupun lanjutan harus berfokus pada keselamatan pasien baik dalam tatanan rumah sakit, komunitas maupun perawatan di rumah. Keselamatan pasien sudah menjadi prioritas dalam aspek pelayanan rumah sakit dan sudah menjadi tuntutan dalam pelayanan kesehatan Safety patient atau keselamatan pasien merupakan tanggung jawab semua pihak yang berkaitan dengan pemberi pelayanan kesehatan. Keselamatan pasien rumah sakit ada di dalam Panduan Nasional Keselamatan Pasien Rumah sakit Departemen Kesehatan Republik Indonesia tahun 2006. Tujuannya ialah mengidentifikasi resiko keselamatan pasien dan program menekan atau mengurangi kejadian tidak diharapkan. Insiden Keselamatan Pasien adalah peristiwa dan kondisi yang tidak disengaja yang mengakibatkan atau berpotensi menyebabkan cedera dapat dicegah pada pasien, Insiden Keselamatan Pasien (IKP) yang terdiri dari Kejadian Tidak Diharapkan (KTD), Kejadian Nyaris Cedera (KNC), Kejadian Tidak Cedera (KTC) dan Kondisi Potensial Cedera (KPC)2. Keselamatan pasien adalah prioritas utama dan harus segera dilaksanakan di rumah sakit karena dapat menyebabkan cedera langsung kepada pasien, juga terkait dengan kualitas dan citra rumah sakit serta standar pelayanan yang harus dipenuhi oleh rumah sakit itu terkait dengan versi 2012 dari standar akreditasi mengacu pada Joint Commission International(JCI).

Dalam mencegah kejadian yang tidak diharapkan maka perawat memiliki peran yang penting dalam mendidik pasien dan keluarga. Keselamatan dalam pemberian pelayanan dapat 
ditingkatkan dengan keterlibatan pasien yang merupakan partner dalam proses pelayanan. Karena itu, di rumah sakit harus ada sistem dan mekanisme mendidik pasien dan keluarga tentang kewajiban dan tanggung jawab pasien dalam asuhan keperawatan. Dengan pendidikan tersebut diharapkan keluarga memberikan informasi yang benar, jelas, lengkap, dan jujur, mengetahui kewajiban dan tanggung jawab pasien dan keluarga, mengajukan pertanyaan pertanyaan untuk hal yang tidak dimengerti, menerima dan memahami konsekuensi pelayanan, mematuhi instruksi dan menghormati peraturan rumah skait, memperlihatkan sikap menghormati dan tenggang rasa dan memenuhi kewajiban finansial yang disepakati

\section{PEMBAHASAN}

Menurut Undang Undang Republik Indonesia Nomor 52 Tahun 2009, keluarga merupakan unit terkecil dalam masyarakat yang terdiri dari suami, istri, atau suami, istri dan anaknya atau ayah dan anaknya atau ibu dan anaknya. Anak yang dimaksudkan dalam pengertian ini adalah anak yang belum menikah. Apabila ada anak yang sudah menikah dan tinggal bersama suami/istri atau anak anaknya, maka anaknya tersebut dapat menjadi keluarga tersendiri (keluarga lain atau keluarga baru). Selain itu, juga terdapat defenisi khusus untuk keluarga, yaitu salura individu seseorang yang tidak diikat dalam hubungan keluarga, hidup dan makan serta menetap dalam satu rumah. Defenisi keperawatan tentang keluarga dipengaruhi keterlibatan personal diri perawat dengan keluarganya sendiri dan pengalaman klinik. Oleh karena itu sangat disarankan agar perawat tidak menggunakan nilai. Nilai yang ada pada dirinya saat memberikan asuhan keperawatan pada keluarga binaan. Umumnya perawat menggunakan defenisi keluarga yang merujuk pada dua atau lebih yang saling tergatung satu sama lainnya dan memberikan dukungan secara emosional, fisik, dan atau keuangan (Hanson, 2005). Namun demikian perawat perlu mengadopsi dan bekerja bersama keluarga dengan defenisi yang lebih luas. Hal hal yang menjadi bukti penting keluarga sebagai unit terkecil masyarakat dapat dijelaskan bahwa keluarga terbentuk untuk memenuhi dua tujuan penting yaitu memenuhi kebutuhan masyarakat dan memenuhi kebutuhan anggota keluarga (Friedman et al.2005). Keluarga memenuhi kebutuhan masyarakat melalui penghasilan dan sosialisasi anggota keluarga, unit dasar (keluarga) yang kuat mempengaruhi perkembangan individu yang menentukan kesuksesan atau kegagalan hidup individu tersebut (Friedman et al,2003). Keluarga adalah penyangga antara individu dan masyarakat. Keluarga memenuhi kebutuhan individu melalui penyediaan kebutuhan individu melalui penyediaan kebutuhan dasar (makanan, tempat tinggal, pakaian dan kasih 
sayang). Pembentukan keluarga merupakan upaya pemberian dukungan pada pasangan dalam keluarga dengan memenuhi kebutuhan afektif, seksual, dan sosioekonomi.

Friedman (2010) menyebutkan bahwa keluarga memiliki fungsi yaitu fungsi afektif, fungssi sosialisasi, fungsi reproduksi, fungsi ekonomi dan fungsi perawatan kesehatan. Fungsi keluarga dapat terlaksana melalui upaya-upaya yang diwujudkan melalui peran suami dan istri secara bersama-sama dalam mencapai fungsi dalam keluarga. Fungsi perawatan kesehatan tercermin pada aspek penyediaan kebutuhan fisik makanan, pakaian tempat tinggal dan perawatan kesehatan. Keluarga sebagai fungsi perawatan kesehatan merupakan tempat mempelajari konsep kesehatan, promosi kesehatan, pemeliharaan kesehatan, pencegahan penyakit, dan managemen penyakit. Fiedmen, Bowmen, dan Jones (2003) menyatakan bahwa fungsi perawatan kesehatan keluarga merupakan fungsi keluarga dalam merawat anggota keluarga dengan masaah kesehatan yang memberdayakan sumber daya keluarga dan berbasis keluarga. Fungsi perawatan kesehatan keluarga bukan hanya sebagai fungsi esensial dan dasar keluarga, tetapi fungsi yang mengemban fokus sentral dalam keluarga agar keluarga berfungsi dengan baik dan sehat. Namun pemenuhan fungsi perawatan kesehatan untuk semua anggota keluarga dapat menjaadi sulit karena tantangan internal dan eksteral. Berbagai masalah atau kesulitan dalam memberikan perawatan keluarga dapat berasal dan struktur keluarga dan sistem pelayanan kesehatan. Anggota anggota memerlukan kemampuan berupa pengetahuan dan keterampilan untuk melakukan perawatan terhadap suatu kondisi sakit. Selain itu sistem pelayanan kesehatan yang mudah diakses keluarga akan mendukung keluarga memenuhi fungsi perawatan kesehatan.kelurga perlu mengenali sebagian besar kebutuhan untuk melakukan perawatan kesehatan diri mereka namun juga membutuhkan pelayanan professional maupun pelayanan kesehatan seperti rumah sakit, apotek, serta asuransi kesehatan yang mendukung fungsi keperawatan kesehatan keluarga. Selain itu, kendala keluarga dalam memberikan perawatan kesehatan pada seluruh anggota keluarga antara lain kurangnya akses pelayanan kesehatan, kurang dana/pembiyaan, pendidikan, tingkat pendapatan yang kurang sehingga kurang dapat memanfaatkan pelayanan kesehatan yang tersedia.

Keluarga sebagai klien yaitu melihat keluarga sebagai keseluruhan individu yang terdapat di dalam keluarga. Pendekatan ini menggambarkan bahwa keluarga merupakan tampilan keluarga yang terlihat dan individu individu anggota keluarga menjadi latar belakang keluarga. Fokus dari keluarga sebagai klien adalah bagaimana individu anggota keluarga berdampak pada keluarga secara menyeluruh (Stanhope dan Lancaster,2012). Cara 
pandang perawat dalam menerapkan sebagai klien memerlukan kemampuan perawat dalam merespon ekspresi verbal dan non verbal seluruh anggota keluarga saat terdapat anggota keluarga yang sakit. Rumusan diagnose keperawatan yang akan ditegakkan akan tidak lagi berfokus pada kenutuhan anggota keluarga sebagai individu namun dampak masalah kesehatan pada salah satu anggota keluarga pada seluruh anggota keluarga

Keluarga berperan secara aktif dalam menjaga keselamatan pasien di pelayanan kesehatan yaitu memberikan informasi pasien yang benar, jelas, lengkap dan jujur, mengetahui dan melaksanakan kewajiban serta tanggung jawab pasien maupun keluarga, keluarga dapat mengajukan pertanyaanpertanyaan untuk hal yang tidak dimengerti, keluarga memahami dan menerima konsekuensi pelayanan, keluarga harus dapat memperlihatkan sikap menghormati dan tenggang rasa dalam proses bersama tim medis untuk mengelola pasien, serta keluarga memenuhi kewajiban finansial yang disepakati. Tugas kesehatan keluarga menggambarkan kemapuan keluarga untuk mengenali masalah masalah kesehatan yang terjadi di antara anggota keluarga dan memberikan perawatan pada anggota keluarga yang sakit. Tugas kesehatan keluarga terdiri dari lima tugas yaitu

1. Mengenali masalah kesehatan pada anggota keluarga

Upaya memahami masalah kesehatan belum dilakukan oleh banyak keluarga. Seringpula terjadi anggapan yang salah karena informasi yang diperoleh secara turun temurun atau pengaruh dari aspek budaya, yang terjadi kurang memperhatikan kondisi kesehatan diri. Ketidakmampuan keluarga mengenali masalah kesehatan dapat disebabkan oleh kurang pengetahuan, menyangkal tentang keberadaan atau keparahan penyakit akibat rasa takut tentang konsekuensi dari diagnosis atau masalah, dan perilaku atau filosopi hidup

2. Membuat keputusan yang berkaitan dengan upaya pengobatan/perawatan

Keputusan keluarga untuk mengatasi masalah kesehatan seringkali terkendala karena keputusan keluarga menunggu nasehat dari ornag tua atau orang yang dituakan dalam keluarga besar. Ketidakmampuan keluarga membuat keputusan dapat disebabkan oleh kegagalan mengenali sifat dan cakupan masalah, rendahnya kepentingan masalah, perasaan bingung dan pasrah akibat kegagalan menyelesaikan masalah, kurangnya pengetahuan, ketidakmampuan memutuskan usaha dari pilihan penyelesaian masalah, konflik opini antar anggota keluarga tentang pilihan penyelesaian masalah, kurangnya pengetahuan tentang layanan kesehatan di komunitas.

3. Melakukan upaya perawatan untuk menghilangkan kondisi sakit pada anggota keluarga 
Keluarga perlu mengenali berbagai kondisi yang dapat menjadi penyebab gangguan kesehatan atau ancaman kesehatan yaitu kondisi yang dapat menyebabkan munculnya penyakit, kecelakaan atau kegagalan mengenali potensi kesehatan seseorang. Seperti adanya faktor resiko terkait penyakit, ancaman infeksi silang dari penyakit menular, ukuran keluarga yang melebihi sumber daya yang mampu disediakan dan kesalahan teknik pemberian makan atau kebiasaan makan yang tidak sehat.

4. Pemeliharaan kesehatan pada lingkungan rumah yang kondusif

Keluarga diharapkan mampu melkukan pemeliharaan lingkungan di dalam dan sekitar rumah sehingga dapat menoptimalkan lingkungan dalam memelihara kesehatan

5. Memanfaatkan pelayanan kesehatan yang ada

Keluarga diharapkan memilikipengetahuan tentang fasilitas kesehatan di sekitar rumah dan menggunakan fasilitas pelayanan kesehatan tersebut untuk pemeliharaan keluarga sehat. Sikap keluarga terhadap fasilitas pelayanan kesehatan masyarakat penting diketahui perawat agar dapat mengarahkan keluarga dalam memperoleh pelayanan kesehatan yang sesuai

\section{PENUTUP}

\section{Kesimpulan}

Keselamatan pasien adalah suatu sistem yang membuat asuhan keperawatan terhadap pasien menjadi lebih aman. Perawat merupakan salah satu sumber daya manusia yang sangat dibutuhkan untuk mencapai kinerja yang optimal. Berdasarkan hal tersebut, penerapan pasien safety oleh perawat sangat penting dalam upaya mengurangi insiden kecelakaan kerja pada pasien dan dalam asuhan keperawatan penting melibatkan pasien dan keluarga agar terjalinnya kerja sama yang baik

\section{Saran}

Fasilitas kesehatan sebaiknya memiliki sistem dan mekanisme mendidik pasien dan keluarganya mengenai kewajiban dan tanggungjawab dalam asuhan pasien. Dengan pendidikan tersebut diharapkan pasien dan keluarganya dapat berpartisipasi dengan baik, dan mendapat informasi dalam mengambil keputusan tentang asuhan yang diterimanya. 


\section{REFERENSI}

Abubakar Nabillah, Neffrety Nilamsari. (2017). Pengetahuan dan Sikap Keluarga Pasien Rawat Inap Rumah Sakit Haji Surabaya . Jurnal manajemen kesehatan universitas Airlangga $3(1)$.

http://jurnal.stikes-yrsds.ac.id/index.php/JMK/article/view/79

Baihaki Ahcmad. (2017).Buku Ajar- Managemen Keselamatan Pasien. Malang: UB Press

Hadi Irwan. (2017). Managemen Keselamatan Pasien. Yogyakarta: Deepublish

Ismainar Hetty. (2019). Keselamatan Pasien Di Rumah Sakit. Yogyakarta: Deepublish

Juniarti Nanda Hani, Ahmad Ahid Mudayana. (2018). Penerapan Standar Keselamatan Pasien Di Rumah Sakit Umum Daerah Provinsi Nusa Tenggara Barat. Jurnal Kesehatan Poltekkes Ternate, 11(2)

$\underline{\text { http://ejournal.poltekkesternate.ac.id/ojs/index.php/juke/article/view/91 }}$

Lombogia Angelita, Julia Rottie, Michael Karundeng. (2016). Hubungan Perilaku Perawat dalam Melaksanakan Keselamatan Pasien (Patient Safety) di Ruang Akut Instalansi Gawat Darurat RSUP Prof. DR. R. D. Kandou Manado. e-journal Keperawatan (e-Kp) Volume 4 (2) https://ejournal.unsrat.ac.id/index.php/jkp/article/view/12916

Nies A Mari, Melanie McEwen. (2019). Keperawatan Kesehatan Komunitas dan Keluarga. Singapore: Elsevier

Salawati Liza. (2020). Penerapan Keselamatan Pasien di Rumah Sakit. Jurnal Averrous Volume 6(1)

https://ojs.unimal.ac.id/index.php/averrous/article/download/2665/1651

Simamora, R. H. (2019). Buku ajar pelaksanaan identifikasi pasien. Uwais Inspirasi Indonesia.

Triwibowo, C.,dkk. (2016). Handover Sebagai Upaya Peningkatan Keselamatan Pasien (Patient Safety) Di Rumah Sakit. Jurnal Keperawatan Soedirman.11 (2).

http://jks.fikes.unsoed.ac.id/index.php/jks/article/view/646 
Yusuf Muhammad. (2017). Penerapan Patient Safety Di Ruang Rawat Inap Rumah Sakit Umum Daerah Dr. Zainoel Abidin. Jurnal keperawatan universitas Syiah Kuala Banda Aceh $5(1)$

http://jurnal.unsyiah.ac.id/JIK/article/view/8766 